\title{
Pancasila dalam Pusaran Diskursus Liberalisme versus Komunitarisme ${ }^{1}$
}

\section{Otto Gusti Madung ${ }^{2}$}

\begin{abstract}
This paper attempts to show that a democratic order is not built on the procedural ethics as assumed by liberals, but it is required a substantive ethical foundation. The reason is the democratic system is not contained of atomistic individuals without social relations. A democratic process always moves in a society characterized by social relations and the various formation processes of complex communities. Democracy is built on formal yet fragile collective identity. In the context of Indonesia, Pancasila is an expression of the collective identity. As a collective identity, Pancasila has no ends and always in the process of being and find themselves in a new way. At the end of the paper, two methods; deliberative and agonistic democracy method are presented. These methods are offered by contemporary political philosophy in resolving conflicts of value in the middle of pluralism.
\end{abstract}

\begin{abstract}
Abstrak: Tulisan ini coba menunjukkan bahwa sebuah tatanan demokratis tidak cukup dibangun di atas etika prosedural seperti diasumsikan kaum liberal, tapi membutuhkan landasan etis substantif. Alasannya, sistem demokratis tidak diisi oleh individu-individu atomistik tanpa relasi sosial. Sebuah proses demokrasi selalu bergerak dalam sebuah masyarakat yang ditandai dengan relasi-relasi sosial dan berbagai proses formasi komunitas yang kompleks. Demokrasi dibangun di atas identitas kolektif yang formal, namun sekaligus rapuh. Untuk konteks bangsa Indonesia, Pancasila adalah ungkapan identitas kolektif tersebut. Sebagai identitas kolektif Pancasila tak pernah selesai, melainkan selalu berada dalam proses menjadi dan menemukan diri secara baru. Pada bagian akhir tulisan dipresentasikan dua metode yakni metode demokrasi deliberatif dan agonistik sebagai cara yang ditawarkan filsafat politik kontemporer dalam menyelesaikan konflik-konflik nilai di tengah faktum pluralisme.

Kata kunci: liberalisme, komunitarisme, Pancasila, identitas kolektif, demokrasi, deliberasi, agonistik.
\end{abstract}

1 Dipresentasikan pada acara Simposium Filsafat Indonesia bertemakan "Mencari Sosok Filsafat Indonesia" di Jakarta pada tanggal 19-20 September 2014. Simposium ini diselenggarakan atas kerja sama STF Driyarkara, Institut Prestasi Nusantara/MURI dan Kementerian Pendidikan dan Kebudayaan RI.

2 Penulis adalah dosen HAM dan Filsafat Politik di STFK Ledalero, Flores, Nusa Tenggara Timur. 


\section{Pendahuluan}

Pada awal masa kemerdekaan bangsa Indonesia terjadi perdebatan antara Mohamad Hatta dan Soepomo tentang landasan ideologis bangsa Indonesia. Hatta menganjurkan liberalisme sebagai basis ideologis bangsa Indonesia dan berhasil memasukkan ide kebebasan berserikat, berkumpul dan mengemukakan pendapat ke dalam konstitusi NKRI (bdk. Psl 28 UUD 45). Sementara itu Soepomo mengusulkan konsep negara integralistik karena integralisme dianggap sesuai dengan nilainilai budaya bangsa Indonesia yakni azas gotong-royong dan kekeluargaan.

Seperti para politisi pejuang kemerdekaan Indonesia pada umumnya, kedua politisi ini memiliki wawasan pemikiran politik yang mahaluas. Hatta dan Soepomo sudah cukup lama menggeluti dan mendalami pemikiran politik Barat. Liberalisme Hatta dipengaruhi oleh pemikiran Adam Smith, John Locke dan J.J. Rousseau. Cita-cita Revolusi Prancis yakni liberte, egalite dan fraternite bagi Hatta juga merupakan cita-cita Indonesia merdeka. ${ }^{3}$ Sedangkan konsep negara integralistik Soepomo tak dapat dibayangkan tanpa pergulatan intelektual yang mendalam dengan konsep integralisme Adam Müller yang berada dalam tradisi filsafat Hegel. ${ }^{4}$

Di tengah pragmatisme yang melanda pertarungan politik di tanah air, perdebatan ideologis menjadi sepi dan dipandang tidak relevan secara politik. Padahal sebuah politik yang bermartabat selalu dibangun di atas ideologi atau identitas kolektif yang jelas. Dalam sejarah bangsa Indonesia Pancasila merupakan identitas kolektif yang terbukti mampu menyatukan kebhinekaan bangsa Indonesia.

Apa artinya Pancasila sebagai philosofische grondslag, sebagai identitas bangsa dalam situasi politik kontemporer baik pada tatanan bangsa pun tatanan global? Kutipan dari Chantal Mouffe berikut mungkin perlu untuk direfleksikan untuk memahami identitas secara tepat: "Tampaknya dalam ranah identitas kolektif, seolah-olah orang dapat menciptakan sebuah "kekitaan kolektif" yang hanya bertahan jika "mereka" dihancurkan." Mouffe ingin memberikan wawasan bahwa tak pernah ada identitas yang sudah selesai, yang ada adalah proses konstruksi identitas kolektif yang tak pernah berakhir. "Niemals Identität,

3 Bdk. Mohamad Hatta, Kumpulan Karangen (1) (Jakarta: Penerbit Bulan Bintang, 1976), p. 11.

4 Bdk. Franz Magnis-Suseno, Pijar-Pijar Filsafat (Yogyakarta: Penerbit Kanisius, 2005), p. 58. 
immer Identifizierungen"- "Tak pernah ada identitas, tapi proses identifikasi."

Refleksi tentang Pancasila sebagai basis ideologi dan identitas bangsa Indonesia tetap urgen. Sebab sebuah bangsa hanya dapat bertahan kalau ada roh (Geist) yang mempersatukannya. Untuk itu Pancasila perlu ditafsir kembali dan ditemukan aktualitasnya. Di tengah era globalisasi yang telah menempatkan Indonesia sebagai bagian dari tatanan masyarakat global, tafsir kembali Pancasila hanya mungkin dan relevan jika ditempatkan dalam diskursus ideologi masyarakat global.

Dalam tulisan ini saya coba menempatkan Pancasila di tengah pusaran arus ketegangan antara dua aliran filsafat poltik kontemporer: liberalisme dan komunitarisme. Seperti dikemukakan pada awal tulisan ini, diskursus seputar liberalisme versus komunitarisme sesungguhnya juga sudah muncul pada saat berdirinya republik ini ketika terjadi perdebatan antara Soepomo dengan konsep negara integralistiknya dan Mohamad Hatta yang memperjuangkan agar hak-hak individual dimasukkan ke dalam UUD 45.

\section{Komunitarisme versus Liberalisme}

Pluralitas merupakan salah satu ciri khas masyarakat moderen. Kehidupan bersama dalam masyarakat moderen diwarnai kebhinekaan pandangan, nilai, ideologi dan tradisi kultural. Kebhinekaan ini tidak hanya mewarnai ruang publik, tapi juga menyusup hingga ke ranah privat. Faktum pluralitas melahirkan sejumlah pertanyaan mendasar: apakah masih ada elemen normatif yang dapat mempersatukan sebuah masyarakat plural? Bagaimanakah kompleksitas pluralitas tersebut harus dihadapi?

Dari perspektif filsafat sosial diskusi tentang kohesi sosial berawal dari perdebatan liberalisme versus komunitarisme. Perdebatan ini berawal dari karya John Rawls berjudul $A$ Theory of Justice yang diterbitkan tahun 1971. Buku ini merupakan salah satu karya filsafat politik terpenting pada abad ke-20 dan telah meletakan landasan kokoh bagi liberalisme dalam diskursus filsafat politik. Rawls berangkat dari pertanyaan dasar, apa saja ciri khas institusi-institusi sosial yang adil? Rawls tidak bertanya tentang apa itu tindakan yang adil atau apa saja ciri khas seorang manusia yang baik. Objek formal dari konsep keadilan adalah struktur dasar masyarakat. Rawls menulis: "Keadilan adalah

5 Chantal Mouffe, pber das Politische. Wider die kosmopolitische Illusion (Frankfurt am Main: Suhrkamp, 2007), p. 12. 
keutamaan pertama institusi-institusi sosial." ${ }^{\prime}$

Apa itu masyarakat yang adil? Rawls memberikan pendasaran atas teorinya dengan menggunakan eksperimen intelektual tentang original position (posisi asali). Rawls berada dalam tradisi teori kontrak sosial yang pernah dikembangkan oleh Hobbes, Locke, Rousseau dan Kant. Ia merevitalisasi tradisi kontrak sosial yang cukup lama terlupakan. Tujuannya ialah membangun konstruksi etis-argumentatif sebuah masyarakat yang adil.

Sebuah catatan singkat tentang term "adil". Dalam bahasa Indonesia fair berarti adil seperti juga just. Namun keduanya punya perbedaan mendasar, fair lebih berarti keadilan prosedural. Sebuah proses dikatakan adil jika tidak terjadi manipulasi. Sedangkan just berarti keadilan substansial. Contoh, dalam sebuah undian yang dibuat dengan sangat fair, bisa saja hadiah semuanya jatuh ke tangan orang-orang kaya. Sementara orang-orang miskin tidak mendapat apa-apa. Secara substansial kita dapat mengatakan itu tidak adil (just), tapi secara prosedural tidak terjadi ketidakadilan ${ }^{7}$

Menurut Rawls, para peserta posisi asali memiliki beberapa karakter yang diidealisasikan yakni memiliki rasionalitas strategis, absennya rasa empati dan iri hati satu sama lain, sehat secara jasmani dan rohani, memiliki interesse akan makna keadilan dan mengembangkan konsep pribadinya tentang kebahagiaan. Para anggota dalam posisi asali memiliki pemahaman tertentu tentang norma-norma dasar alternatif, antara lain konsep tentang keadilan historis seperti utilitarisme dan juga model-model baru termasuk konsep keadilan dari Rawls sendiri.

Dalam posisi asali tersebut orang mengambil keputusan di balik "cadar ketaktahuan" (Schleier des Nichtwissens). ${ }^{8}$ Itu berarti mereka tidak mengetahui posisi sosial dan taraf hidupnya di masa depan, jenis kelamin, identitas asalnya, kepentingan, sikap, talenta, bakat dan lain-lain. Pilihan yang harus dijatuhkan dari model-model etika yang tersedia dalam posisi asali berorientasi pada aturan dengan memilih sistem norma yang paling menguntungkan dalam kondisi paling sulit.

Berdasarkan syarat-syarat di atas, demikian Rawls, para peserta dalam posisi asali akan menerima dua macam prinsip keadilan: ${ }^{9}$ Pertama, setiap orang mempunyai hak yang sama atas kebebasan-kebebasan dasar

6 John Rawls, Eine Theorie der Gerecbtigkeit (Frankfurt am Main: Suhrkamp, 1979/1971), p. 19.

7 Bdk. K. Bertens, Pengantar Etika Bisnis (Yogyakarta: Kanisius, 2000), p. 102.

8 Bdk. John Rawls, Eine Theorie, p. 38.

9 Bdk. Ibid., p. 77. 
yang paling luas yang dapat dicocokkan dengan kebebasan-kebebasan yang sejenis untuk semua orang. Di sini Rawls menganut egalitarianisme. Kebebasan-kebebasan seperti hak berpendapat, hak untuk mengikuti hati nurani, hak berkumpul, dan sebagainya harus tersedia dengan cara yang sama untuk semua orang. Masyarakat tidak diatur dengan adil, kalau hanya satu kelompok boleh mengemukakan pendapatnya atau semua warga negara dipaksakan untuk memeluk satu agama. Kebebasankebebasan itu harus seluas mungkin, tetapi ada batas juga. Batas bagi kebebasan satu orang adalah kebebasan dari semua orang lain. Sama sekali tidak adil, jika saya begitu bebas, sehingga orang lain tidak bebas lagi.

Kedua, ketidaksamaan sosial dan ekonomis diatur sedemikian rupa sehingga: a) Menguntungkan terutama orang-orang yang minimal beruntung, dan serentak juga; b) melekat pada jabatan-jabatan dan posisiposisi yang terbuka bagi semua orang dalam keadaan yang menjamin persamaan peluang yang fair. Prinsip 2 bagian a disebut prinsip perbedaan (difference principle). Supaya masyarakat diatur dengan adil, tidak perlu semua orang mendapat hal-hal yang sama. Dengan itu Rawls menolak egalitarianisme radikal. Boleh saja ada perbedaan dalam apa yang dibagi dalam masyarakat. Tetapi perbedaan itu harus sedemikian rupa sehingga harus menguntungkan mereka yang minimal beruntung. Misalnya, boleh dianggap adil saja, jika negara menyelenggarakan kursus ketrampilan untuk orang miskin atau memberi tunjangan kepada janda dan yatim piatu, sedangkan kepada orang lain yang cukup mampu tidak diberikan apa-apa. Mengapa hal itu dianggap adil? Karena kita merumuskan prinsip ini ketika kita berada dalam posisi asali. Dengan prinsip perbedaan ini Rawls sebenarnya meletakkan landasan etis untuk Welfare state moderen.

Prinsip 2 bagian $b$ disebut prinsip persamaan peluang yang fair. Adanya jabatan atau posisi penting mengakibatkan juga ketidaksamaan dalam masyarakat. Sudah dari sediakala jabatan-jabatan tinggi sangat didambakan orang bersama fasilitas dan privilegi yang melekat padanya. Hal ini tidak boleh dianggap kurang adil, asalkan jabatan dan posisi itu pada prinsipnya terbuka untuk semua orang.

Antara prinsip-prinsip di atas terdapat hubungan. Prinsip pertama "kebebasan yang sedapat mungkin sama" harus diberi prioritas mutlak. Prinsip ini tidak pernah boleh dikalahkan oleh prinsip-prinsip lain. Keuntungan ekonomis tidak dapat dijadikan dasar legitimasi untuk melanggar hak-hak dasar. Sedangkan prinsip "persamaan peluang yang fair" harus ditempatkan di atas prinsip perbedaan. Pada skala nilai dalam 
masyarakat adil yang dicita-citakan Rawls, paling atas harus ditempatkan hak-hak kebebasan klasik yang adalah ham. Lalu harus dijamin peluang yang sama bagi semua warga negara untuk memangku jabatan yang penting. Akhirnya dapat diterima perbedaan sosialekonomis tertentu demi peningkatan kesejahteraan orang-orang yang minimal beruntung.

Relevan untuk diskusi tentang ikatan sosial ialah bahwa menurut Rawls kohesi sosial terbentuk lewat pendasaran rasional atas kedua prinsip keadilan di atas. ${ }^{10}$ Karena kedua prinsip ini dianggap rasional untuk semua manusia, maka keduanya merupakan ungkapan dari sebuah masyarakat yang adil. Kohesi sosial dibangun atas dasar dua prinsip keadilan, atau lebih konkret lagi, atas dasar penataan institusiinstitusi sosial secara liberal-demokratis.

Konsep liberal Rawlsian ini mendapat tanggapan dari kaum komunitarian. Salah satu tanggapan yang penting berasal dari filsuf Michael Walzer. ${ }^{11}$ Komunitarisme memberikan penekanan bahwa norma-norma selalu terjangkarkan dalam komunitas bahasa, kultural dan agama. Dalam setiap komunitas terdapat pandangan moral bersama dan dihayati. Pandangan moral kolektif ini merupakan basis normatif dalam menilai setiap tindakan dalam komunitas. Perpektif komunitarian menunjukkan bahwa manusia tidak dapat dipikirkan sebagai individu atomistik atau "unencumbered self" (Sandel) seperti dirancang dalam antropologi liberal. Manusia dalam pandangan kaum liberal dimengerti sebagai individu yang terisolir dan melayang-layang di ruang kosong serta ditempatkan dalam ruang-ruang hak kebebasan. Dalam kenyataannya, demikian kaum komunitarian, manusia selalu hidup dalam komunitas, tradisi dan ikatan sosial. Sebuah sistem sosial yang tidak menggubris aspek-aspek sosial ini dan hanya membatasi diri pada pemahaman tentang manusia sebagai pribadi hukum dalam ruang-ruang kebebasan, menghancurkan substansi sosial hidup manusia dan cenderung menghantar masyarakat kepada bahaya individualisasi, atomisasi dan penghancuran nilai solidaritas. Komunitarisme mengembangkan antropologi sosial dengan menghidupkan kembali konsep Aristotelian tentang manusia sebagai makhluk sosial.

${ }^{10}$ Bdk. Michael Reder, Hanna Pfeifer, Maria-Daria Cojocaru, „Was hält Gesellschaft zusammen? Eine Einführung”, in: idem, Was hält Gesellschaft zusammen? Der gefährdete Umgang mit Pluralität (Stuttgart: Kohlhammer, 2013), p. 9.

${ }^{11}$ Bdk. Michael Walzer, Sphären der Gerechtigkeit. Ein Plädoyer für Pluralität und Gleichbeit (Frankfurt am Main: Campus Verlag, 1992). 
Titik pijak pandangan Walzer tentang keadilan adalah komunitas politis yang terbentuk dari kesadaran kolektif akan kesamaan bahasa, sejarah dan budaya. Keadilan merupakan sebuah konsep relatif yang selalu dikaitkan dengan tradisi dan struktur setiap komunitas. Walzer menolak pandangan Rawls yang mencari prinsip-prinsip keadilan di balik "cadar ketaktahuan". Menurut Walzer, prinsip keadilan hanya dapat dikonstruksi dalam konteks pengalaman kultural dan historis yang konkret. Mengabaikan konsep tentang pengalaman nilai yang lahir dari konteks budaya dan sejarah merupakan sebuah bentuk ketidakadilan, demikian tesis Walzer. Setiap komunitas memiliki pemahamannya sendiri tentang keadilan yang harus dipratikkan dan direfleksikan. Keadilan bukan prinsip abstrak transhistoris, tapi selalu dalam bentuk realisasi konkret. Karena itu Walzer bertolak dari pandangan bahwa makna sosial barang-barang menentukan distribusinya. Distribusi hanya bersifat adil dalam hubungan dengan makna barang-barang tersebut dalam sebuah komunitas. Keadilan berakar dalam "benda-benda yang mengungkapkan cara hidup bersama". ${ }^{12}$

Berseberangan dengan liberalisme, komunitarisme menekankan perbedaan-perbedaan sosial dalam bentuk ikatan kekeluargaan, budaya, negara atau komunitas moral. Model-model satuan sosial ini merupakan basis bagi kohesi sosial. Jika ikatan-ikatan sosial tersebut tidak mendapat perhatian cukup atau jika tatanan kohesi sosial dipandang sebagai prinsip formal abstrak, maka akan muncul bahaya ambruknya ikatan sosial. Berbeda dengan liberalisme, komunitarisme memberikan penekanan lebih pada aspek komunitas. Komunitarisme juga bersikap skeptis terhadap konsep rasionalitas tatanan masyarakat.

\section{Pancasila, Liberalisme dan Komunitarisme}

Hubungan antara negara dan masyarakat seperti dikembangkan kaum komunitarian dapat dijadikan model relasi antara negara dan masyarakat, politik dan agama di Indonesia berbasiskan Pancasila. Seperti antropologi komunitarian, Pancasila juga memberikan penekanan pada dimensi sosial hidup manusia.

Selaras dengan pandangan kaum komunitarian, Pancasila sebagai ideologi bangsa menghendaki agar konsep keadilan dan hukum berpijak pada pandangan hidup baik serta mengandaikan konsep hidup baik. Tanpa pilihan makna dan nilai hidup baik yang dihayati serta berpijak

${ }^{12}$ Ibid., hlm. 443 
pada tradisi etis-religius dan ideologis, sistem hukum moderen (hak dan keadilan) akan remuk seketika.

Pancasila dalam kaca mata komunitarisme dapat dipandang sebagai sebuah catatan kritis atas patologi masyarakat liberal dan memunculkan beberapa rujukan positif untuk sebuah kehidupan bersama. Ada beberapa hal yang perlu digarisbawahi dalam menafsirkan Pancasila dari perspektif komunitarian sebagai basis kehidupan masyarakat Indonesia yang plural.

\section{Pancasila dan Patologi Liberalisme}

Dari perspektif komunitarisme Pancasila dapat memberikan penekanan pada beberapa persoalan sentral Indonesia yang moderen. Prinsip moderen seperti demokrasi dan faham hak-hak asasi manusia yang menjadi titik pijak politik di Indonesia pasca reformasi tetap menunjuk pada pertanyaan seputar pandangan hidup, pertanyaan yang berhubungan dengan substansi dan pemahaman tentang manusia. Pancasila adalah jawaban atas pertanyaan ini. Faham hak asasi manusia sebagai sebuah konsep universal membutuhkan locus kontekstualisasi di Indonesia agar menjadi bagian dari hidup masyarakat. Pancasila mencegah bahaya privatisasi konsep hidup baik seperti dipraktikkan dalam masyarakat liberal. Namun di sisi lain harus tetap disadari kalau pancasila hanya menjadi relevan jika selalu terbuka ditafsir lagi dalam terang nilai-nilai kemanusiaan universal seperti konsep HAM.

Bahwa jawaban yang human atas pertanyaan tentang orientasi makna dan nilai dapat ditemukan dalam sebuah masyarakat, sangat bergantung pada vitalitas sosial dari tradisi, sumber-sumber kultural, agama, model-model etos serta tatanan sosial di mana makna dan nilai tersebut dirawat dan dihayati. Pancasila merupakan suatu model pengawetan dan vitalisasi tradisi tersebut. Untuk itu Pancasila harus selalu ditematisasi dalam diskursus di ruang publik. Dengan demikian Pancasila mengambil bagian dalam proses pembentukan kesadaran kolektif bangsa Indonesia.

Diferensiasi dan atomisasi sistem-sistem interaksi moderen hidup dan hanya berfungsi atas dasar prasyarat-prasyarat kultural. Tatanan hukum negara yang berpijak pada konsep hak-hak asasi manusia betul merupakan syarat yang seharunya (necessary condition), tapi bukan yang mencukupi (sufficient condition) bagi sebuah tatanan masyarakat yang adil dan sejahtera. Juga konstitusi dan hukum yang paling rasional sekalipun belum menjadi jaminan dalam berperang melawan 
masyarakat yang egoistis, intoleran, kriminal, akrab dengan kekerasan, korup, rakus dan kehilangan orientasi makna. Korupsi, lemahnya solidaritas sosial menggambarkan kian mengeringnya orientasi makna tersebut. Pancasila sebagai ideologi dan sistem etika bangsa memberikan rambu-rambu untuk keluar dari pelbagai krisis etika publik yang tengah melanda bangsa kita.

\section{Pancasila: Paradigma Diferensiasi dalam Relasi Antara Negara dan Agama}

Perlu dicatat bahwa Pancasila hanya dapat diterima sebagai basis ideologi masyarakat Indonesia yang plural ini jika ia tetap belajar dari konsep liberal tentang pembedaan antara negara dan masyarakat, politik dan agama. Pilihan makna dan nilai pandangan hidup serta konsep hidup baik dan pemeliharaannya harus berlangsung dalam konteks masyarakat liberal atau bebas. Negara dapat memberikan garansi otonomi hukum dan etis kepada warga negara sebagai pribadi juridis di mana setiap pribadi dapat mendefinisikan dirinya sebagai pribadi etis dan membangun hubungan komunitarian dengan yang lainnya.

Dialektika penuh ketegangan antara negara dan agama, keadilan dan konsep tentang hidup baik ditunjukkan oleh mantan Presidan Mahkamah Konstitusi Jerman, Ernst Wolfgang Böckenförde. Böckenförde merumuskan secara tepat esensi sekaligus paradoks yang harus dihadapi sebuah negara demokratis moderen: "Der freiheitliche, säkularisierte Staat lebt von Voraussetzungen, die er selbst nicht garantieren kann" - "Negara liberal-sekuler hidup dari syarat-syarat yang tak dapat dijaminnya sendiri." 13

Paradoksi ini, demikian Böckenförde, harus diterima setiap negara liberal yang mau menghargai pluralitas dan menyelamatkan kebebasan individu. Sebuah negara demokratis moderen hanya mungkin eksis secara legitim jika ia mampu menjamin dan melindungi kebebasan setiap warganya. Di satu sisi kebebasan individu merupakan tujuan dan dasar keberadaan sebuah negara. Akan tetapi di sisi lain inti dari kebebasan tersebut yakni suara hati tidak pernah boleh dan tidak dapat diatur menurut norma-norma hukum positif. Sebab ketika negara lewat hukum positif masuk ke dalam ranah privat kebebasan suara hati, ia sesungguhnya telah menjadi totaliter. Paradoksi yang dikemukakan

${ }^{13}$ Ernst Wolfgang BQckenfQrde, Staat, Gesellschaft, Freheit. Studien zur Staatstheorie und zum Verfassungsrecht (Frankfurt am Main: Suhrkamp, 1976), p. 60. 
Böckenförde di atas merupakan jalan yang telah dan tetap dilewati pemikiran dan praktek politik Eropa moderen. Jalan ini telah menghantar mereka keluar dari konflik berdarah dan perang antara agama dan kelompok etnis yang melanda Eropah pada abad ke-17. Dan hingga kini konsep negara liberal-sekular tetap mampu menjaga perdamaian umum.

Kebebasan manusia terungkap lewat keputusan otonom dan atas pertimbangan suara hati yang tidak pernah boleh serta tidak dapat diintervensi oleh instansi luar. ${ }^{14}$ Kebebasan hanya dapat meregulasi dirinya dari dalam, dari substansi moral setiap individu dan homogenitas sebuah masyarakat. Bahaya totalitarisme mulai mengintip ketika negara misalnya lewat hukum positif mau mengatur suara hati dan keutamaan pribadi warga negara. Di sini negara berambisi mengatur segala-galanya termasuk cara berpikir dan moralitas warganya yang seharusnya mustahil dapat dilaksanakannya. Ambisi negara tersebut menciptakan konflik dan membahayakan perdamaian umum sebab ia menyangkal adanya pluralitas budaya, agama, tingkah laku dan kebebasan berpikir dalam sebuah negara moderen.

Pancasila sebagai sebuah ideologi masyarakat Indonesia yang mulitikultural harus mampu menangkal tendensi komunitarisme yang coba mempersoalkan kembali distingsi antara negara dan masyarakat, antara pribadi juridis dan etis serta mau menghidupkan sebuah negara "kebenaran" (regim agama, ideologi, pandangan hidup).

Tendensi komunitarian yang intoleran ini muncul di Indonesia terutama dalam bentuk fundamentalisme agama. Kaum fundamentalis melakukan teror dan menghalalkan kekerasan untuk membasmi kelompok-kelompok lain. Dengan membajak demokrasi prosedural kelompok fundamentalis telah berhasil menciptakan dan menggolkan sejumlah produk hukum yang antimultikultural seperti UndangUndang Pornografi serta ratusan peraturan daerah yang bernuansa Syariah. ${ }^{15}$ Cita-cita untuk membangun sebuah negara dengan berbasiskan ideologi atau agama tertentu merupakan sebuah bentuk kemunduran sejarah peradaban umat manusia. Untuk mengatasi hal ini demokrasi prosedural harus dilengkapi dengan substansi demokrasi yang membatasi kesewenangan kekuasaan dan kesewenangan kehendak

${ }^{14}$ Bdk. Franz Magnis -Suseno, Etika Politik. Prinsip-prinsip Moral Dasar Kenegaraan Moderen (Jakarta: Gramedia Pustaka Utama, 1999), p. 348.

15 Bdk. Adnan Buyung Nasution, Demokrasi Konstitusional, (Jakarta: Penerbit Buku Kompas, 2011), p. 122. 
mayoritas. Substansi demokrasi adalah hak-hak asasi manusia yang juga terkandung dalam nilai-nilai Pancasila.

Pancasila tidak menghendaki adanya agama negara di Indonesia. Namun itu tidak berarti, Pancasila sepakat dengan pandangan kaum liberal yang memandang agama sebagai persoalan privat semata. Pancasila menghendaki agar nilai-nilai agama diterjemahkan menjadi moralitas publik. Di sini konsep ketuhanan dalam Pancasila berperan seperti agama sipil (civic religion) yang berurusan dengan moralitas publik dan tidak mencampuri moralitas serta keyakinan pribadi. Atau seperti dirumuskan Yudi Latif:

...dalam kerangka ketuhanan menurut Pancasila, boleh saja seseorang secara pribadi tidak memeluk agama formal (sebagai agnostik atan babkan ateis). Akean tetapi, dalam kebidupan publiknya harus tetap menghormati nilai-nilai Ketuhanan-keagamaan seperti dikehendaki Pancasila berdasarkan hasil kesepakatan konstitusional, sehingga tidak diperkenankan menyebarkan propaganda untuk menolak atau membenci agama. $^{16}$

Mengingat pentingnya peran publik agama, Pancasila membuat koreksi atas tesis "privatisasi" agama kaum liberal dan menganjurkan paradigma diferensiasi dalam relasi antara agama dan negara. Sebab, "ketika agama tersudut dari ruang publik ke ruang privat, yang muncul adalah ekspresi spiritualitas personal yang terputus dari kehidupan publik. Sebailiknya, politik sekuler memandang rendah nilai-nilai agama dan mengabaikan signifikansi moral ketuhanan. Akibat yang ditimbulkan oleh situasi saling mengabaikan ini adalah spiritualitas tanpa pertanggungjawaban sosial, dan politik tanpa jiwa." ${ }^{17}$ Untuk itu fundamentalisme, baik fundamentalisme agama maupun fundamentalisme sekuler harus dihindari. Maraknya korupsi di tengah pesatnya perkembangan agama-agama di Indonesia merupakan bukti kasat mata bahwa agama masih dihayati sebagai ritus kesalehan privat dan belum menjadi kekuatan moral di ruang publik.

Peran publik agama menuntut agama untuk membela sendiri kebebasannya serta kebebasan agama-agama lain. Agama juga dapat mempersoalkan tendensi absolutisme dunia sekuler dan absolutisme kekuasaan negara yang membahayakan kehidupan manusia tanpa harus

\footnotetext{
${ }^{16}$ Yudi Latif, Negara Paripurna. Historisitas, Rasionalitas dan Aktualitas Pancasila (Jakarta: Kompas Gramedia, 2011), p.112.

${ }^{17}$ Ibid., p. 104.
} 
merebut dan mendominasi seluruh ranah kehidupan manusia. ${ }^{18} \mathrm{Di}$ tengah arus modernisasi yang ditandai dengan kolonialisasi sistem teknologi dan birokrasi kekuasaan yang anonim atas dunia kehidupan (Lebenswelt), agama tampil sebagai sumber mata air moralitas dan pemberi rambu-rambu etis.

Ketuhanan dalam kerangka Pancasila mengungkapkan komitmen bangsa Indonesia untuk menata kehidupan politik-publik atas dasar nilai-nilai moral universal agama-agama serta budi pekerti yang luhur. Krisis moral yang dihadapi masyarakat moderen serta fenomen kebangkitan agama-agama dalam masyarakat sekular membuat paradigma ketuhanan dalam kerangka Pancasila menjadi penting dan semakin relevan.

Dalam masyarakat Barat sejak tahun 90-an paradigma sekuler yang meminggirkan agama ke ruang privat mulai goyah dan tema agama kembali meramaikan diskursus di ruang publik. ${ }^{19}$ Habermas misalnyanya yang menganggap dirinya "religius unmusikalisch" (tak berbakat secara religius) menyadari kembali akan pentingnya peran agama di ruang publik dan mengembangkan konsep masyarakat post-sekuler. Mengapa masyarakat liberal-sekuler kembali kepada agama?

Mungkin salah satu jawaban atas pertanyaan ini adalah ramburambu kritis salah seorang teolog Katolik abad ini, Hans Kung, yang dialamatkan kepada masyarakat moderen sekular yang mau mendepak agama ke raung privat irasionalitas: "Kendatipun manusia mewajibkan dirinya untuk taat pada norma-norma moral, satu hal tetap tak dapat dilakukan manusia tanpa agama: memberikan pendasaran atas keniscayaan dan universalitas kewajiban-kewajiban moral." 20

Pendasaran terakhir tak tergoyahkan tentang keharusan dan universalitas norma-norma moral, demikian Kung, tak dapat berpijak pada argumentasi filosofis abstrak semata-mata. Filsafat hanya mampu menyentuh intelek manusia. Sementara keharusan nilai-nilai moral harus dapat menggugah ranah perasaan manusia, ruang di mana agama-agama dapat menembusnya dan bergerak. Karena itu krisis moralitas masyarakat moderen menuntut peran aktif agama-agama dalam ruang publik.

${ }^{18}$ Bdk. Ibid., p. 109.

19 Bdk. Otto Gusti Madung, "Etos Global dan Dialog Peradaban”, Kompas 27 Februari 2010, p.6.

${ }^{20}$ Bdk. Hans Kung, "Leitlinien zum Weiterdenken”, dalam: Hans-Martin SchoenherrMann, Miteinder Leben Lernen (Muncehen: Piper Verlag, 2008), p. 387. 


\section{Pancasila, Pluralisme dan Demokrasi}

Pada masa 1934 hingga 1938 Bung Karno mengalami masa pembuangan di Kota Ende, Flores. ${ }^{21}$ Di tempat ini ia antara lain menjalin persahabatan dengan sejumlah misionaris Katolik asal Belanda. Di Ende yang kala itu masih sangat terpencil Soekarno boleh menggunakan perpustakaan para misionaris SVD (Societas Verbi Divini - Serikat Sabda Allah) dan berdiskusi dengan para misionaris Belanda di Biara St. Yosef. Konon dalam sebuah percakapan dua misionaris Belanda yakni Johanes Bouma dan Gerardus Huijtink yang dalam perjalanan waktu telah menjadi teman akrab Bung Karno pernah mengajukan dua pertanyaan penting kepada Bung Karno yang mendorongnya berpikir serius tentang Pancasila. Pertama, "di mana tempat mamamu yang beragama Hindu itu di dalam negara yang mayoritas Muslim?" Kedua, "di mana tempat orang-orang Flores yang mayoritas Katolik ini dalam negara yang Marxis dan mayoritas Muslim itu?'”2

Bung Karno merumuskan Pancasila sebagai basis ideologis yang dapat mempersatukan Indonesia yang plural. Sebagai simbol identitas kolektif bangsa Pancasila mengatasi identitas-identitas komunal sehingga setiap pribadi, kelompok, pandangan hidup dan agama dapat mewujudkan dirinya secara otentis tanpa harus membahayakan yang lain. Pancasila adalah sebuah konstruksi politis yang dibangun untuk memperkokoh kohesi sosial di tengah sebuah masyarakat yang plural. Tantangan yang dihadapi bangsa Indonesia dewasa ini sudah berbeda dari masa-masa awal kemerdekaan. Sebagai bagian dari masyarakat global bangsa Indonesia ikut mengambil bagian dalam perwujudan nilainilai global seperti demokrasi, hak-hak asasi manusia dan ekonomi pasar. Keterbukaan terhadap masyarakat global membuat realitas plural menjadi semakin kompleks. Pertanyaan muncul, apa artinya Pancasila sebagai jaminan kohesi sosial di tengah pluralisme Indonesia yang kompleks itu? Bagaimana Pancasila sebagai jaminan kohesi sosial di satu sisi dipadukan dengan prinsip penghargaan terhadap pluralisme di sisi lain di tengah proses demokratisasi yang dilalui bangsa Indonesia?

Sebelum membahas pertanyaan ini kita melihat tiga pengertian konsep pluralisme yang menjadi rujukan dalam perdebatan seputar kohesi sosial dalam filsafat politik dewasa ini. Pertama, pluralisme

${ }^{21}$ Tim Nusa Indah, Bung Karno dan Pancasila: Ilham dari Flores untuk Nusantara (Ende: Penerbit Nusa Indah, 2006).

22 John Dami Mukese, "Bung Karno, SVD dan Pancasila", dalam Antonio Camnahas dan Otto Gusti Madung (Ed.), ... ut verbum Dei currat. 100 Tahun SVD Indonesia (Maumere: Penerbit Ledalero, 2013), p. 299. 
digunakan dalam perspektif netral untuk menggambarkan kondisi masyarakat yang berbhineka dan terdiferensiasi. Di dalam masyarakat demokratis kebebasan berpikir dan berpendapat dijunjung tinggi. Setiap warga bebas memilih dan menentukan pandangan hidup, pekerjaan atau pandangan politik sesuai seleranya. Dalam konteks ini pluralisme sebagai deskripsi keberagaman sosial yang faktis merupakan esensi sebuah masyarakat demokratis.

Kedua, pluralisme dipandang sebagai sebuah nilai positif. ${ }^{23}$ Di sini pluralisme tidak diartikan secara deskriptif sebagai gambaran masyarakat heterogen, tapi dari sudut pandang normatif diinterpretasi sebagai basis nilai sebuah kehidupan bersama. Justru karena setiap orang boleh bebas berpikir, bertindak dan percaya, maka bisa muncul apa yang dinamakan sebuah masyarakat liberal di mana manusia dapat hidup berdampingan secara damai. Pluralisme di sini memastikan ikatan sosial dan ditafsir sebagai garansi kohesi sosial.

Ketiga, pluralisme mendapat konotasi negatif. Pluralisme dipandang sebagai bahaya untuk kesatuan sosial. Alasannya, keanekaragaman pada pelbagai bidang (ideologi, politik, budaya, dll) menghancurkan kohesi sosial. Pluralisme ditafsir sebagai gejala lemahnya norma sosial atau ungkapan hilangnya norma kolektif. Pluralisme merupakan simtom raibnya solidaritas sosial masyarakat kompleks. Egoisme, alienasi budaya dan krisis solidaritas sering dikeluhkan. Hancurnya negara atau prinsipprinsip demokrasi dalam negara yang disebabkan oleh lobbysme dan orientasi pribadi dalam pengambilan keputusan politik diduga berakar pada pluralisme. Di balik kritikan ini muncul kerinduan akan tuntutan sebuah kesatuan sosial, entah sebuah identitas kultural atau basis nilai politik kolektif. Kritikan ini mengungkapkan tuntutan bahwa masyarakat liberal membutuhkan lebih dari sekeder kesetaraan formal. Tidak cukup kalau warga secara formal hanya memiliki hak-hak yang sama. Masyarakat membutuhkan sebuah pandangan kolektif yang bersifat substansial, sebab hanya dengan cara itu norma-norma sosial dapat diberi pendasaran. Bagaimana ikatan emosional kolektif itu dapat dirumuskan atau diciptakan dan sejauh mana jangkauan tuntutan normatif yang terkandung di dalamnya masih terus diperdebatkan.

Penjelasan di atas menunjukkan bahwa dalam masyarakat moderen proses individualisasi dan tuntutan komunitas selalu berada dalam tegangan. Di satu sisi otonomi dan penentuan diri merupakan ciri

${ }^{23}$ Bdk. Isaiah Berlin, "On the Pursuit of the Ideal", in The New York Review of Books 35, 1988, p. 11-18. 
dasariah masyarakat moderen. Warga ingin membuat keputusan tentang hidupnya kendati keputusan itu berseberangan dengan tuntutan common sense dan komunitas. Di sisi lain manusia selalu merupakan bagian dari sebuah komunitas bahasa, kultural, sejarah, politis dan normatif. Jika dalam perspektif ini sebuah masyarakat tidak lagi menunjukkan kesatuan komunal, maka masyarakat tersebut berada dalam bahaya kehancuran atau sebuah kehidupan bersama yang damai terancam.

Dalam filsafat sosial, Isaiah Berlin antara lain membuat penelitian intensif tentang relasi antara pluralisme dan proses formasi komunitas. Ia berpandangan bahwa masyarakat moderen dibangun atas dasar nilai kebebasan dan kesetaraan yang bersifat universal. Akan tetapi kedua nilai dasar ini sering tidak berjalan harmonis dan bahkan dalam masyarakat plural berseberangan satu sama lain. Jika terdapat tendensi harmonisasi nilai-nilai tersebut secara absolut, maka masyarakat tersebut, demikian Berlin, sudah berada di ambang bahaya totalitarisme. ${ }^{24}$ Karena itu masyarakat moderen niscaya sangat bergantung pada diskursusdiskursus publik tentang penerapan nilai-nilai tersebut dalam persoalanpersoalan sosial politik yang konkret. Diskursus tentang aplikasi nilainilai kolektif tersebut dalam situasi konkret dapat menciptakan kohesi sosial.

Namun penekanan berlebihan pada nilai-nilai kolektif mengandung bahaya munculnya politik identitas yang eksklusif dan intoleran. Kendatipun demikian demokrasi tetap membutuhkan identitas kolektif dalam takaran yang wajar. Dalam membangun identitas kolektif tersebut masyarakat plural sering menghadapi konflik nilai.

Dalam sejarah bangsa Indonesia misalnya kita mencatat perdebatan seputar relasi antara negara dan agama (Islam) yang berawal dari polemik antara Soekarno dan Mohammad Natsir. ${ }^{25}$ Soekarno merupakan representasi dari kelompok nasionalis sekuler yang memperjuangkan pemisahan tegas antara negara dan agama. Sedangkan Mohammad Natsir menyuarakan aspirasi golongan nasionalis islami yang menghendaki pertautan yang erat antara agama dan negara, sebab agama tidak hanya mengatur relasi antara manusia dan Tuhan, tapi juga manusia dan manusia dalam sebuah tatanan politik. Dewasa ini wacana ini masih terus digaungkan oleh pelbagai kelompok dalam Islam yang dapat

${ }^{24}$ Bdk. Ibid., p. 16.

${ }^{25}$ Bdk. Ahmad Suhelmi, Polemik Negara Islam: Soekarno vs Natsir (Jakarta: UI Press, 2012). 
dikategorikan ke dalam dua kubu, yakni Islam "liberal" dan Islam "literal". ${ }^{26}$ Kelompok Islam liberal meneruskan gagasan Soekarno tentang pemisahan antara agama dan negara. Gagasan tentang sekularisasi di kalangan Islam dipopulerkan kembali oleh Nurcholish Madjid dan dikembangkan oleh kelompok Islam liberal seperti Ulil Abshar Abdalla, Luthfi Assyaukanie dan Akhmad Sahal. Mereka berpendapat bahwa Islam liberal merupakan sebuah gerakan untuk menanggapi persoalan seputar relasi antara Islam dan tantangan modernitas seperti pluralisme, hak-hak individu, demokrasi dan konsep negara. ${ }^{27}$ Sebagai antitesis atas pandangan Islam liberal lahirlah kelompok Islam literal yang diwakili oleh Adian Husaini, Hartono Ahmad Jaiz, Ja'far Umar Thalib dan Habib Rizieq. Kelompok ini memperjuangkan terbentuknya negara Islam. Alasannya, dalam sejarah pernah ada negara Islam yakni negara Madinah yang memiliki konstitusi pertama di dunia yakni Piagam Madinah. Negara Madinah dipimpin oleh Nabi Muhammad sebagai kepala negara. Negara Madinah diatur menurut syariat Islam dan hukum adat. ${ }^{28}$

Untuk menyelesaikan ketegangan-ketegangan seperti ini masyarakat sangat bergantung pada diskusi-diskusi publik guna menemukan solusi politisnya. Sebagai panduan dalam perdebatan politis di ruang publik Pancasila tidak boleh dilihat sebagai rumusan mati. Ia harus ditematisasi dan ditafsir kembali secara rasional agar menjadi identitas kolektif yang hidup. Dalam masyarakat plural guna menyelesaikan konflik nilai, filsafat politik menawarkan dua jalan yang menjadi model formasi identitas kolektif dalam sebuah tatanan demokratis. Di tengah proses demokratisasi yang dijalani oleh bangsa Indonesia kita dapat menempatkan Pancasila sebagai nilai dan simbol identitas kolektif bangsa dalam kerangka dua model tersebut. Model dimaksud adalah konsep demokrasi deliberatif Jürgen Habermas dan teori demokrasi radikal Chantal Mouffe yang mendekati posisi kaum komunitarian.

Seluruh karya filosofis Habermas dituntun oleh sebuah ide pencerahan. Ia ingin mendorong emansipasi dan demokrasi, menggerakkan masyarakat untuk berpartisipasi dalam proses sosial politik serta memberi kontribusi lebih bagi diskursus publik. Ide dasar

${ }^{26}$ Bdk. Wilden Sena Utama, "Negara (dan) Islam. Sekitar Polemik Soekarno dan Natsir" Prisma. Majalah Pemikiran Sosial Ekonomi, Edisi Khusus/Vol. 32, No. 2 dan No. 3, 2013, p. 262.

${ }^{27}$ Bdk. Ibid.

${ }^{28}$ Bdk. Ibid., p. 263. 
filsafatnya bertitik tolak dari situasi perbincangan biasa sehari-hari. Habermas menekankan bahwa manusia tidak mungkin tidak berbicara satu sama lain. Dalam percakapan, mereka dengan cara berbeda-beda membangun komunikasi. Itulah ide dasar teori diskursus. Jadi bahasa tidak hanya merupakan bentuk intersubjektivitas, tapi juga serentak sebuah langkah fundamental menuju emansipasi dan komunikasi. Sebab bersama ucapan kalimat pertama „dinyatakan juga secara jelas intensi sebuah konsensus universal dan tanpa paksaan". ${ }^{29}$

Basis dari teori demokrasi ini adalah sebuah konsep masyarakat yang terbangun dari tiga komponen yakni Lebenswelt, ruang publik (Öffentlichkeit) dan sistem. Dalam Lebenswelt atau dunia kehidupan terjangkar model-model komunikasi manusiawi. Secara intuitif manusia bertindak komunikatif dan mencari komunikasi dalam konteks keseharian dunia kehidupan. Sementara itu prinsip publisitas bertugas untuk menangkap semua persoalan yang muncul di Lebenswelt dan menyuarakannya di ruang publik serta memberi tekanan pada sistem politik. Ranah sistem mengatur bahwa manusia juga bertindak strategis, artinya mengejar tujuan tertentu secara fungsional.

Dengan merujuk pada pengalaman dasariah komunikasi, secara etis manusia mengenal bahwa norma-norma hanya dapat diakui sebagai legitim jika dapat disetujui oleh semua. Prinsip etika diskursusnya ialah, "bahwa yang boleh menuntut validitas hanyalah norma-norma yang mendapat (juga secara antisipatoris) persetujuan dari semua yang berpartisipasi dalam diskursus praktis". ${ }^{30}$ Di balik prinsip ini terdapat asumsi bahwa seseorang yang mulai berargumentasi secara implisit selalu sudah menerima aturan-aturan komunikasi yang tak dapat disangkalnya. Barangsiapa bicara harus sudah selalu menerima aturan-aturan tersebut, jika tidak ia akan terjebak dalam kontradiksi performatif. Jadi etika diskursus bertolak dari realitas Lebenswelt manusia. Etika diskursus adalah sebuah etika formal. Dalam tradisi pencerahan Kantian Habermas berpandangan bahwa manusia dapat berkomunikasi secara rasional dan membangun konsensus dalam sebuah diskursus. Rasionalitas komunikatif ini memberi pendasaran bagi sebuah etika dialogis. Norma-norma bagi kehidupan bersama hanya dapat digali dari argumentasi dialogal dan bukan dari spekulasi akal budi monologis.

${ }^{29}$ Jürgen Habermas, Technik und Wissenschaft als Ideologie (Frankfurt am Main: Suhrkamp, 1968), p.163.

${ }^{30}$ Jürgen Habermas, Moralbewusstsein und kommunikatives Handeln (Frankfurt am Main: Suhrkamp, 1983), p. 103. 
Dalam banyak karyanya Habermas berhasil menunjukkan bagaimana pandangan filosofis dapat diterapkan secara politis. Salah satu contohnya adalah konsep "demokrasi deliberatif". ${ }^{11}$ Artinya, proses formasi opini dan kehendak harus diinstitusionalisasi. Dengan demikian sebanyak mungkin warga masyarakat dapat berpartisipasi dalam diskursus-diskursus tentang pertanyaan-pertanyaan kritis menyangkut kehidupan bersama. Publisitas yang terbentuk secara spontan, kreatif dan bersifat desentralistis itu menjamin pluralitas opini publik. Tujuan dari proses ini adalah konsensus rasional yang terbentuk secara komunikatif. Hanya dengan jalan ini norma-norma kehidupan bersama mendapat legitimasi cukup dan mendorong warga untuk menerapkannya dalam Lebenswelt-nya masing-masing.

Atas dasar pertimbangan di atas, bagi Habermas kohesi sosial atau untuk konteks Indonesia Pancasila sebagai identitas kolektif hanya berhasil atau menjadi tujuan yang legitim jika struktur dan prosedur deliberatif dibentuk yang menopang pandangan etika diskursus. Jika masyarakat menciptakan prosedur di mana semua orang terkait mengambil bagian di dalamnya dan tujuan prosedur tersebut adalah terbangunnya konsensus rasional untuk konflik-konflik sosial, maka design deliberatif tersebut merupakan jaminan bagi kohesi atau kesatuan sosial. Pancasila sebagai hasil dari prosedur deliberatif yang menggambarkan rasionalitas komunikatif memperkokoh kesatuan dalam masyarakat Indonesia yang plural.

Sebagai antitesis atas konsep demokrasi deliberatif, dalam diskursus filsafat politik muncul term "postdemokrasi". Dalam tafsiran Chantal Mouffe demokrasi sesungguhnya ditandai dengan paradoks yang tak terakomodasi dalam pandangan demokrasi deliberatif. ${ }^{32}$ Paradoks itu muncul karena demokrasi menjembatani dua aspek yang bertentangan yakni kebebasan individual dan prinsip kesetaraan. Menurut Mouffe, ketegangan antara keduanya tak mungkin terjembatani dan merupakan roh pendorong gerakan demokrasi.

Pada tahun 1980-an bersama Ernesto Laclau, Mouffe meletakkan basis filsafat sosial bagi pandangannya tentang demokrasi. Yang sosial menurutnya tidak terbentang secara positif di hadapan kita, melainkan senantiasa mengaktualisasikan dirinya sebagai sebuah bentuk diskursivitas yang kompleks. Bagi Mouffe bukan referensi pada dunia empiris yang menciptakan makna, melainkan makna hanya terkonstruksi di tengah-tengah diskursus sosial dan politik. Diskursus

31 Jürgen Habermas, Faktizität und Geltung (Frankfurt am Main: Suhrkamp, 1992).

32 Bdk. Chantal Mouffe, Das demokratische Paradox (Wien: Turia Verlag, 2008). 
adalah sebuah totalitas sosial yang senantiasa berubah secara dinamis. Atas dasar dinamika tersebut dan ketidakmungkinan mereduksi yang sosial pada makna tunggal, maka masyarakat selalu dipersoalkan dan rapuh. Karena itu selalu muncul pertarungan-pertarungan wacana baru guna menstabilisasi diskursus. Dan kondisi inilah yang dikenal dengan yang politis.

Dengan bertolak dari filsafat politik dan teori negara Carl Schmitt, Mouffe membeberkan pandangannnya. Esensi yang politis menurut Schimitt adalah distingsi antara kawan dan lawan. Masyarakat terbentuk dari identitas-identitas kolektif yang secara niscaya mengeksklusi dan bertarung satu sama lain. Di sini Schmitt mulai melancarkan kritikannya atas liberalisme. Pertama, liberalisme, demikian Schmitt, terlalu terfokus pada individu dan mengabaikan identitas-identitas kolektif. Kedua, liberalisme juga terlalu yakin dengan kemampuan konsensus sosial. Mouffe menunjukkan simpatinya pada konsep demokrasi sebagai pluralisasi pertarungan-pertarungan politis tersebut. Namun Mouffe berseberangan dengan Schmitt sebab pertimbangan-pertimbangan Schmitt cenderung melahirkan masyarakat totaliter. Karena itu Mouffe menganjurkan transformasi konseptual dari antagonisme kekuatankekuatan sosial yang niscaya menuju agonisme. Bukan musub (Feind), tapi lawan (Gegner) yang posisinya dapat direbut dengan penuh semangat dalam demokrasi. Konsep lawan mengungkapkan bahwa setiap orang berhak untuk mempertahankan posisinya. Dalam arti tertentu lawan dipahami sebagai musuh yang legitim.

Dari persepektif demokrasi radikal Mouffe mengkritisi konsep demokrasi deliberatif Habermas. Menurutnya, Habermas dan pemikir liberal lainnya gagal memahami yang politis sebagai arena pertarungan terbuka. Tentu saja Mouffe tidak memahami pertarungan tersebut sebagai perdebatan antara individu, melainkan pertarungan di tengah realitas-realitas wacana. Karena itu dalam pertimbangannya ia menaruh perhatian khusus pada relasi-relasi kekuasaan yang terstruktur secara diskursif. Kritikan kedua ialah bahwa teori-teori demokrasi liberal mengabaikan relasi dalam sebuah masyarakat. Seperti Walzer, Mouffe menekankan moment militansi (Leidenschaft) yang ditafsirkannya sebagai motor penggerak proses demokrasi. "Politik selalu berkaitan dengan sebuah dimensi keberpihakan yang penuh militansi (...). Justru itu yang hilang dewasa ini pada glorifikasi demokrasi tanpa militansi dan keberpihakan."33

${ }^{33}$ Chantal Mouffe, Über das Politische. Wider die kosmopolitische Illusion (Frankfurt am Main: Suhrkamp, 2007), p. 40. 
Akhirnya konsep demokrasi radikal bermuara pada sebuah kritik atas pemahaman rasionalitas liberal. Para pemikir liberal, demikian Mouffe, menganut pengertian akal budi yang formal tapi sekaligus sangat monolitis. Pemikir postmodernisme Wolfgang Welsch mengeritik konsep rasionalitas monologal Habermas karena Habermas ingin mengembalikan pluralitas kepada kesatuan kendatipun ia tak dapat menunjukkan bagaimana kesatuan itu harus dipikirkan. ${ }^{34}$ Dengan demikian pluralitas opini masyarakat digeser begitu saja ke ranah privat irasionalitas.

Dari sudut pandang teoretis yang antiesensialistik pluralisme bukan sekedar sebuah faktum yang terpakasa harus dipikul dengan kertak gigi atau yang coba dibendung, melainkan sebuah prinsip aksiologis. Pada tataran konseptual dari esensi demokrasi moderen prinsip aksiologis tersebut dianggap konstitutif dan dipandang sebagai sesuatu yang harus diterima dan dikembangkan. ${ }^{35}$

Dibandingkan dengan teori demokrasi deliberatif, demokrasi radikal memberi penekanan bahwa pada tempat pertama kohesi sosial tidak diciptakan lewat rasionalitas komunikatif atau prosedur deliberatif, tapi melalui pertarungan wacana politis. Pancasila menjadi identitas kolektif ketika ia menjadi objek pertarungan wacana. Dengan itu Pancasila dijauhkan dari bahaya monopoli interpretasi yang menjerumuskannya ke dalam ideologi dalam pengertian kesadaran palsu seperti dipraktikkan sepanjang masa Orde Baru. Ketika perdebatan politis tentang Pancasila sebagai identitas bangsa ditampilkan secara militan dalam pluralitas konteks dan ideologi, para warga akan merasa menjadi bagian dari yang politis. Dengan itu terjadi proses identifikasi warga dengan komunitas politis bernama Indonesia. Dengan memberi penekanan pada konsensus, teori demokrasi delibaratif kurang memperhatikan fungsi formasi komunitas dari pluralisme dan pertarungan wacana. Untuk konteks Indonesia yang plural pertarungan wacana perlu dikembangkan terus guna menciptakan Indonesia sebagai sebuah komunitas politik. Pancasila tidak cukup dalam terang teori delibaratif hanya dimengerti sebagai sebuah konsensus rasional. Ia harus dikonstruksikan secara terus-menerus dalam pertarungan wacana. Dengan itu Pancasila akan menciptakan yang politis dan warga merasa dilibatkan dalam komunitas politis.

${ }^{34}$ Bdk. Wolfgang Welsch, Vernunft. Die zeitgeössische Vernunftkritik und das Konzept der transversalen Vernunft (Frankfurt am Main: Suhrkamp, 1995), p. 139.

${ }^{35}$ Chantal Mouffe, Das demokratische, p. 35. 


\section{Penutup}

Pancasila dirumuskan sebagai basis ideologis dalam arti identitas kolektif yang merekatkan Indonesia yang berbhineka menjadi sebuah komunitas politis. Kekuatan ini sudah terbukti ketika Indonesia merdeka didirikan oleh para pendiri bangsa Indonesia. Namun dalam perjalanan sejarah Pancasila sering mengalami proses dogmatisasi sehingga kehilangan relevansi politisnya sebagai identitas kolektif.

Di tengah proses demokratisasi dan keterbukaan terhadap dunia global Pancasila perlu ditafsir kembali dan ditempatkan dalam pertarungan wacana politik kontemporer. Proses demokratisasi yang ditapaki bangsa Indonesia sejak masa reformasi cenderung terperangkap dalam demokrasi prosedural minus kesejahteraan rakyat dan keadilan sosial. Proseduralisme adalah salah satu titik lemah demokrasi liberal dan menjadi sasaran kritik kaum komunitarian. Dalam perspektif komunitarisme, Pancasila dapat menjadi basis normatif dan identitas kolektif dalam membangun Indonesia sebagai sebuah tatanan politis yang demokratis. Setiap demokrasi membutuhkan landasan kultural bersama. Alasannya, sistem demokratis tidak diisi oleh individu-individu atomistik tanpa relasi sosial. Sebuah proses demokrasi selalu bergerak dalam sebuah masyarakat yang ditandai dengan relasi-relasi sosial dan pelbagai proses formasi komunitas yang kompleks. Demokrasi dibangun di atas identitas kolektif yang formal, namun sekaligus rapuh. Untuk konteks bangsa Indonesia Pancasila adalah ungkapan identitas kolektif tersebut. Sebagai identitas kolektif Pancasila tak pernah selesai, melainkan selalu berada dalam proses menjadi dan menemukan diri secara baru. Metode demokrasi deliberatif dan agonistik merupakan dua jalan yang ditawarkan filsafat politik kontemporer dalam menyelesaikan konflik nilai di tengah faktum pluralisme. Pancasila hanya menjadi identitas kolektif yang dihidupi oleh warga kalau ia terbuka untuk diperdebatkan secara rasional di ruang publik dan siap menjadi hanya salah satu alternatif di tengah pertarungan wacana.

\section{Daftar Pustaka}

Berlin, Isaiah. "On the Pursuit of the Ideal", in: The New York Review of Books 35, 1988, p. 11-18

Bertens, K. Pengantar Etika Bisnis. Yogyakarta: Kanisius, 2000

BQckenfQrde, Ernst Wolfgang. Staat, Gesellschaft, Freheit. Studien zur Staatstheorie und zum Verfassungsrecht. Frankfurt am Main: Suhrkamp, 1976 
Dami Mukese, John. "Bung Karno, SVD dan Pancasila", dalam: Antonio Camnahas dan Otto Gusti Madung (Ed.), ... ut verbum Dei currat. 100 Tabun SVD Indonesia. Maumere: Penerbit Ledalero, 2013

Habermas, Jürgen. Technik und Wissenschaft als Ideologie. Frankfurt am Main: Suhrkamp, 1968

Habermas, Jürgen. Moralbewusstsein und kommunikatives Handeln. Frankfurt am Main: Suhrkamp, 1983

Habermas, Jürgen. Faktiəität und Geltung. Frankfurt am Main: Suhrkamp, 1992

Hatta, Mohamad. Kumpulan Karangen (1). Jakarta: Penerbit Bulan Bintang, 1976

Kqng, Hans. "Leitlinien zum Weiterdenken", dalam: Hans-Martin Schoenherr-Mann, Miteinder Leben Lerne. Mqncehen: Piper Verlag 2008

Latif, Yudi. Negara Paripurna. Historisitas, Rasionalitas dan Aktualitas Pancasila. Jakarta: Kompas Gramedia, 2011

Madung, Otto Gusti. "Etos Global dan Dialog Peradaban”. Kompas 27 Februari 2010

Magnis-Suseno, Franz. Etika Politik. Prinsip-prinsip Moral Dasar Kenegaraan Moderen. Jakarta: Gramedia Pustaka Utama, 1999

Magnis-Suseno, Franz. Pijar-Pijar Filsafat. Yogyakarta: Penerbit Kanisius, 2005

Mouffe, Chantal. pber das Politische. Wider die kosmopolitische Illusion. Frankfurt am Main: Suhrkamp, 2007

Mouffe, Chantal. Das demokratische Paradox. Wien: Turia Verlag, 2008

Nasution, Adnan Buyung. Demokrasi Konstitusional. Jakarta: Penerbit Buku Kompas, 2011

Rawls, John. Eine Theorie der Gerechtigkeit. Frankfurt am Main: Suhrkamp, 1979 (1971)

Reder, Michael, Hanna Pfeifer, Maria-Daria Cojocaru. „Was hält Gesellschaft zusammen? Eine Einführung”, in: idem, Was hält Gesellschaft zusammen? Der gefährdete Umgang mit Pluralität. Stuttgart: Kohlhammer, 2013

Sena Utama, Wilden. "Negara (dan) Islam. Sekitar Polemik Soekarno dan Natsir". dalam: Prisma. Majalah Pemikiran Sosial Ekonomi, Edisi Khusus/Vol. 32, No. 2 dan No. 3, 2013 
Suhelmi, Ahmad. Polemik Negara Islam: Soekarno vs Natsir. Jakarta: UI Press, 2012

Tim Nusa Indah. Bung Karno dan Pancasila: Ilham dari Flores untuk Nusantara. Ende: Penerbit Nusa Indah, 2006

Walzer, Michael. Spbären der Gerechtigkeit. Ein Plädoyer für Pluralität und Gleichbeit. Frankfurt am Main: Campus Verlag, 1992

Welsch, Wolfgang. Vernunft. Die zeitgeössische Vernunftkritik und das Konzept der transversalen Vernunft. Frankfurt am Main: Suhrkamp, 1995 